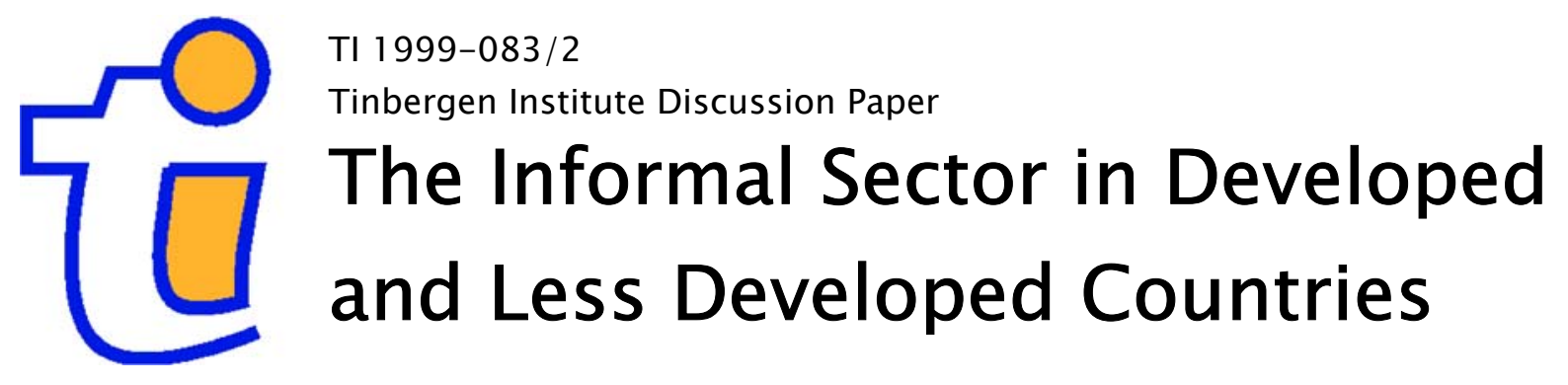

Klarita Gërxhani

Amsterdam Institute for Advanced Labor Studies (AIAS)/Amsterdam School for Social Science Research (ASSR), University of Amsterdam. 
Tinbergen Institute

The Tinbergen Institute is the institute for economic research of the Erasmus Universiteit Rotterdam, Universiteit van Amsterdam, and Vrije Universiteit Amsterdam.

Tinbergen Institute Amsterdam

Roetersstraat 31

1018 WB Amsterdam

The Netherlands

Tel.: $\quad+31(0) 205513500$

Fax: $\quad+31(0) 205513555$

Tinbergen Institute Rotterdam

Burg. Oudlaan 50

3062 PA Amsterdam

The Netherlands

Tel.: $\quad+31(0) 104088900$

Fax: $\quad+31(0) 104089031$

Please send questions and/or remarks of nonscientific nature to wdriessen@few.eur.nl.

Most TI discussion papers can be downloaded at http://www.tinbergen.nl. 


\title{
The Informal Sector in Developed and Less Developed Countries:
}

\section{A Literature Survey}

by

\section{Klarita Gërxhani*}

\begin{abstract}
The main goal of this study is two-fold: (1) to provide a general overview of the contributions to the literature on the informal sector, with a special focus on the Public Choice approach; and (2) to compare these contributions across two institutionally different types of countries: developed and less developed (developing and transition) countries. The paper focuses on the criteria used to define the informal sector, the relationship between the formal and informal economy, tax evasion, and Public Choice analysis. It is stressed throughout this paper that the distinction between the two types of countries is of key importance.
\end{abstract}

Key Words: formal and informal sectors, tax evasion, Public Choice (JEL: H11, H26, O17)

Comments by participants at the ILO Technical Workshop on 'Old and New Facets of Informality' 2001 are gratefully acknowledged. I also thank Michael Ellman, Arthur Schram, Jim Thomas, Friedrich Schneider and an anonymous referee for their useful suggestions.

\footnotetext{
* Amsterdam Institute for Advanced Labor Studies (AIAS)/Amsterdam School for Social science Research (ASSR), University of Amsterdam

address:

Plantage Muidergracht 4

1018 TV Amsterdam

the Netherlands

email: klarita@fee.uva.nl
} 


\section{Introduction}

Once upon a time, economists paid no attention to economic activities carried out outside the formal framework of the economy. Sociologists and anthropologists were the only ones who seemed to consider the existence of such activities. In the 1950s and 1960s, however, the informal dimensions of organizational life became increasingly recognized as important and were accepted as a commonplace topic for research by economists (Blau and Scott, 1963; Gouldner, 1954).

This neglected phenomenon was analyzed in 1972 by the International Labor Office (ILO), under the name informal sector. ${ }^{1}$ As a matter of fact, the informal sector concept originates from a study in a Third World context (Hart, 1971). It was in the Third World countries that the informal sector was initially observed and studied, followed by an increased interest in developed countries. Eventually, important studies about developing countries, a few on former socialist countries (mainly the Soviet Union), and more recently about transition countries started to appear.

Although the significance of the informal sector has varied in different periods and across different countries, society has become more and more aware of the importance of studying it. For a comparison of the size of the informal sector across developed, developing and transition countries, see Table 1. The academic thought about this phenomenon has developed from the earliest studies, which contemplated the informal sector as a marginal or residual activity, to recent ones, which consider it a central aspect of the economic and social dynamics of any country, but especially of the less developed ones. The main issue discussed in the literature has been the significance of the informal sector and its relation to the formal economy. Many studies have contributed to this issue, but there are still contradictions and inconsistent outcomes. This is most obvious when one compares studies of the informal sector in developed countries with studies of the same phenomenon in developing and transition countries. Casual observation suggests that its nature differs significantly among countries with different structures (Cowell, 1990). One of the goals of this paper is to show that this country distinction ${ }^{2}$ is very important in understanding the dynamics of the informal sector. Although the literature is relatively scarce, another goal is to analyze more extensively the informal sector in transition countries. Finally, this paper aims at bringing together and analyzing the contribution of Public Choice theory to the literature on the informal sector. 
This literature survey is organized as follows. The next section provides a summary of the origin of the informal sector concept. Section 3 describes the criteria used to characterize it. Section 4 presents the main theories related to the informal sector in general. Theories related to tax evasion in particular (including Public Choice theories) follow in section 5. Implications of the Public Choice approach are elaborated in section 6 . Section 7 summarizes and concludes. ${ }^{3}$

\section{The genesis of the informal sector concept}

Keith Hart $(1971,1973)$-a social anthropologist- was the first person to bring the term informal sector (in a Third World context) into the academic literature. He introduced the concept of the informal sector to describe a part of the urban labor force, which works outside the formal labor market. ${ }^{4}$ Hart considered the informal sector as almost synonymous for all categories of (small) self-employed individuals. This was thereafter typically used to refer to ways of making a living outside the formal wage economy, either as an alternative to it, or as a means of supplementing income earned within it (Bromley and Gerry, 1979). Even though Hart's original notion of the informal sector is limited to the self-employed, the introduction of the concept made it possible to incorporate activities that were previously ignored in theoretical models of development and in national economic accounts (Swaminathan, 1991). This was an important characteristic of the subsequent use of the term.

In spite of the early work by Hart, the pioneering research on the informal sector is widely considered to be a report of the International Labor Office on employment in Kenya (ILO, 1972). Informality in this report is mainly characterized by the avoidance of government regulations and taxes. Initially, the ILO considered the main aim of the informal sector to be the provision of subsistence to families. It related the growth of the informal sector to its positive effects on employment opportunities and the distribution of income. As a consequence, it argued that solving the problems of the informal sector is only possible if issues like employment relationships and inequality are solved.

Initiated by De Soto (1989), the conceptualization of the informal sector took yet another meaning, by focusing on the regulatory framework. In this approach, the legal status is the main element distinguishing informal from formal activities. It relates the emergence of the informal sector to the policies applied and to transaction costs. It suggests, therefore, that to let the informal sector develop, deregulation of the 
market, greater private property rights, and almost complete abolition of state intervention are needed.

\section{Characterizing the informal sector}

\subsection{Studies about developed countries}

The literature on the informal sector is fraught with terminological confusion (Harding and Jenkins, 1989). Some of the early descriptions of the informal sector are the 'bazaar-economy' and the 'firm-centered economy' (Geertz, 1963); the wartime notion of the 'black market' (Smithies, 1984); popular conceptions about the 'criminal underworld', or images of 'the world turned upside down'. Feige (1989) introduces the term 'underground economy', whereas others have labeled it subterranean, shadow, informal, hidden, parallel, clandestine, second or household. What Feige calls the 'underground economy' is a mixture of activities, however. This explains the terminological confusion and illustrates why different fields (e.g., labor economics, sociology, finance, macroeconomics, statistics or criminology) give it a different meaning. It appeared that no single definition of the underground economy could serve all these domains (Feige, 1989). Therefore, researchers gave up trying to formulate a unique definition, but instead, they have attempted to define the informal sector in accordance with the problem at hand. ${ }^{5}$

I will describe the criteria used to characterize the informal sector. The analysis is summarized in tables 2 (studies of the informal sector in developed countries) and 3 (studies of the informal sector in less developed countries), which are given in the appendix.

The selection of researchers listed in the tables is based on various criteria, for example, the period of study, new developments brought into the field, and the international importance of their findings. The work referred to in tables 2 and 3 is generally considered to cover the main studies in this field.

In both tables, classification is based on three main criteria and various subcriteria. I have adopted the main criteria from Harding and Jenkins (1989). These describe 'the institutional patterns by which the society shapes the informal sector'. They are political, economic and social.

The sub-criteria used with respect to the political aspect of the informal sector are:

1. government regulation; 


\section{2. illegal activities; and}

3. national statistics (GNP).

The idea behind this classification is that it captures the influence of the informal sector on politics [involving lack of government regulation, illegal activities and consequently substantial errors in measuring the national product (GNP)]. A majority of the researchers selected has used the sub-criteria of government regulation to characterize the informal sector (cf. tables 2 and 3). Feige (1981), as will be seen later, emphasizes the 'national statistics' aspect among the criteria he uses.

Although the introduction of the political aspect in the study of the informal sector was an achievement, the basic criterion - which has also received most attention - is the economic one. Here, I will try to cover the most important subcriteria:

(1) labor market or status of labor (including undeclared labor, lack of social benefits, sub-minimum wages, poor working conditions)

As expected, this criterion is essential in characterizing the informal sector. Many studies have based their notion of the informal sector on its consequences for the labor market. Based on this criterion the informal sector is the sum of all income-earning activities with the exclusion of those that involve contractual and legally regulated employment. Among others, Harding and Jenkins (1989), Renooy (1990) and especially the International Labor Office (ILO) emphasize this criterion.

(2) unreported income or tax evasion

Tax evasion appears to be essential as well. In this case, the informal sector is described as the sum of all taxable money income left unreported with the intention to evade taxes. Several researchers, such as Allingham and Sandmo (1972), the Internal Revenue Service (IRS, 1979), Feige (1981, 1990), Tanzi (1982-1986), Frey (1989), Cowell (1990), Alm (1991), and Schneider and Enste (2000), specifically emphasize this criterion.

\section{(3) size of activity}

This criterion used to be quite dominant, especially in the early research on the informal sector. The size of an activity was usually measured by the number of people 
employed in it. For example, Sethuraman (1976) claims that employment of less than ten persons should be considered part of the informal sector. As a result, the smallscale of operation is considered one of the main features of the informal sector activities. This criterion has been particularly helpful in carrying out enterprise surveys. However, table 2 shows that not many researchers of the informal sector in developed countries have used it.

\section{(4) professional status}

Informal workers are defined as 'the sum of the self-employed, family workers and domestic servants' (Hart, 1971, 1973). Despite its frequent use early on, the 'professional status' criterion was not popular for a while. However, it became useful again in the analysis of population censuses and employment surveys in the early 1990s (Charmes, 1990).

\section{(5) regulation or registration of an activity}

Characterization based on regulation considers the relationship between government regulation and the operation of an activity/enterprise. Swaminathan (1991), who has elaborated this criterion most, defines the informal sector enterprises as establishments which are unregistered and unlicensed. Many researchers share this view.

(6) national statistics or GNP accounts ${ }^{6}$

One reason to study the informal sector is the distortions it causes in measuring national accounts (GNP). Feige (1981), who is one of the main supporters of this criterion, defines the informal sector as 'all economic activities, which because of accounting conventions, non-reporting or under-reporting, escape the social measurement apparatus, most notably the GNP accounts'.

The third institutional criterion used in characterizing the informal sector is the social one. Its main sub-criteria are:

\section{(1) social networks and ease of entry}

Surveys on the informal sector indicate that 'A friend of a friend' are the key words in this sector. Breman (1980) emphasizes that the social network is very significant in 
dividing the informal sector into different types. In addition, the International Labor Office (ILO) and various other researchers have often stressed one of the main advantages of the informal sector - ease of entry - which has also been considered as a defining feature of the informal sector. Tables 2 and 3 show that about half of the authors use this criterion in their definitions.

(2) autonomy and flexibility

Many informal sector participants, especially in developed countries, choose to participate in the informal sector because they find more autonomy, flexibility and freedom in this sector than in the formal one. In other words, participants have the freedom of operating their own business; they have flexibility in determining hours or days of operation; they can use and develop their creativity. About half of the researchers selected in tables 2 and 3 , seem to share this criterion.

\section{(3) survival}

This criterion means that the occurrence of informal economic activities is related to needs of its participants to survive. Survival does not appear to be an aspect used in defining the informal sector for developed countries (see table 2). Indeed, Castells and Portes (1989) and ILO (1972 onwards) explicitly mention the exclusion of this criterion in defining the informal sector in these countries. It is important to mention at this stage that the occurrence of the survival criterion has economic consequences for accumulation and growth. A discussion of this relationship will be provided later.

\subsection{Studies about developing and transition countries}

As mentioned above, the informal sector concept originates from a study in a Third World context. "Due to its large impact in developing countries" (Charmes, 1990), there are many studies on the informal sector in these countries. The number on transition countries has increased only recently. It should be noted that an informal sector also existed in the former centrally planned economies, which are now in transition. However, considering the relative isolation of these countries in that period, there are only few studies on this phenomenon in socialist regimes. These are included in the discussion below. 
Table 3 lists a considerable number of researchers who have studied the informal sector in less developed countries. These studies use more or less the same criteria as studies of developed countries. Some important differences do exist, however.

According to table 3, studies on less developed countries use the political criteria to the same extent as studies on developed countries do. With respect to the economic criteria, there are some differences. For example, the sub-criteria 'size of activity' or 'small scale of operation' is used more often in studies on less developed countries. This is most likely because small-scale activities dominate in the informal sector of less developed countries. Distortions caused by the informal sector in measuring national accounts (GNP) do not seem to have attracted much attention. However, the fact that Kaufmann and Kaliberda (1996) and later Anderson (1998) use it, shows that research studies on these countries are becoming more aware of its importance.

As for the social aspect of the informal sector, it is worth mentioning the emphasis that Grossman (1982) gives to the importance of social networks in the informal sector of centrally planned economies. His study points to another typical feature of the informal sector in socialist countries, which is the strong link between the state and non-state activities. These two features seem to have remained even during the transition period (Kaufmann and Kaliberda, 1996).

Finally, tables 2 and 3 indicate a big difference between the two groups of countries regarding the use of the 'survival' sub-criterion in characterizing the informal sector. In addition, various studies have argued that contrary to developed countries, the informal sector in less developed countries generates low income and little, if any accumulation. Furthermore, it is characterized by labor intensive and low technology. These characteristics are inter-related. Because the informal sector is mainly a survival sector, it is labor intensive and yields little accumulation. This issue is still subject of an open debate, however.

\section{Theories related to the informal sector in general}

While the previous section discussed the characteristics of the informal sector, the theories presented here try to explain rather than describe it. More specifically they try to give a view of the relationship between formal and informal activities and to explain participation in the informal sector. I will maintain the structure based on the division of studies on developed and less developed countries. 


\subsection{Studies in developed countries}

\subsubsection{The relationship between the formal and informal sector}

The early studies on the informal sector (1960-1970) considered it to be a separate economic domain. The concepts of a dual economy and social marginality were mentioned as early as 1953 by the 'colonial economist' Boeke. He describes the dual economy as consisting of an urban market economy (of a capitalist nature) on one hand and a rural subsistence economy (static agricultural system of production) on the other. This theory was later criticized for its descriptive rather than explanatory nature, the acceptance of economic dualism, and the assumed autonomous relationship between the formal and informal sectors as opposed to one of domination and subordination (Harding and Jenkins, 1989).

Research in subsequent years showed the importance of the informal sector and discussed its integration into the national economy. The mainstream theory in this period considered informality to be a reality, characterized by 'its own right, with its own rules, conditions and characteristic modes of representation' (Harding and Jenkins, 1989). Supporters of this theory reject the notions of economic dualism and social marginality. They do not see the informal sector as a set of survival activities performed in a marginal society. This theory is characterized by the recognition of the dependency of the informal sector on the formal sector. This dependence could be either complementary (e.g., via sub-contracting activities) or competitive (e.g., unregistered business activities where labor is cheaper and prices are lower).

Feige (1989) contemplates a split up of the unobserved economy in two elements: a monetary sector which utilizes money as a medium of exchange and a non-monetary sector in which the exchange occurs through barter or where goods and services are self-consumed. Due to the unreported income (tax evasion) from both these sectors, the national accounting system is misleading. Consequently, Alford and Feige (1989) suggest that 'information must be treated as an endogenous variable in social systems whenever there exist behavioral incentives and mechanisms to manipulate the information system'. They argue that apparent economic stagnation may partly result from the statistical illusion or distortion (due to the exclusion of the informal sector in the conventional measures of national income).

In a theoretical approach, Renooy's (1990) model of the informal sector yields several distinct features of the informal sector compared to the formal economy: (1) formal regulations and rules are absent; (2) there is often a higher degree of flexibility 
than in the formal labor market; (3) it is not the organization but the form of payment which differs compared to the formal economy; (4) these activities take place both within and outside formal contexts and they strongly interact with each-other; (5) there is no complete information; (6) this sector is highly fragmentary; (7) there is a combination of various (informal) activities because sometimes one activity alone does not produce sufficient income; (8) there is a low entrance threshold to the informal sector; (9) the price of goods and services in this economy is lower than in the formal one; (10) there is a lower capital intensity; (11) there is a lower level of productivity; (12) the informal sector relies predominantly on social/family networks, where subcontracting is its connection with the formal economy; and (13) sometimes there is an absence of channels of access to the formal activities.

An important point of dispute is the effect that the formal economy has on the informal sector. In particular, the question is whether this effect is pro- or anticyclical. In 1991, Lubell suggested that both effects are possible. Whenever the formal economy contracts, individuals become more involved in informal sector activities for lack of alternative ways of earning a living (anti-cyclical). On the other hand, whenever the formal economy expands, the direct and indirect demand for goods and services produced in the informal sector will increase its size. Greenfield (1993) sees the development of the two sectors in a parallel way only. However, he reports that O'Higgins (1989) considers the opposite.

As for the effect of the informal sector on the formal economy, Schneider (1998) reports that in Germany and Austria at least two-thirds of the income earned in the 'shadow economy' is immediately spent in the official economy resulting in considerable (positive) stimulating effect on the official economy. In a study for Belgium, Adam and Ginsburgh (1985) also find a positive relationship between the informal sector and the formal one.

Recently, there has been an increasing contribution in this field from institutional economics. Institutional economists focus their attention on "the relationship between the 'rules of the game' and economic development, considering that institutions are not neutral, but they can substantially stimulate or hinder the process of economic and overall development" (Feige, 1990: 990). Institutions consist of formal institutions (i.e., political and economic rules) and informal institutions (i.e., social norms and traditions). "Changing merely the formal rules will produce the desired results only when the informal norms are complementary to that rule change, 
and enforcement is either perfect or at least consistent with the expectations of those altering the rules" (North, 1997: 19). In addition, as Feige (1997) notes, a clash between formal and informal institutions will yield non-compliant behaviors.

\subsubsection{Motives and causes of informalization}

The majority of analysts agree that economic recession is one of the foremost causes of the development and tenacity of the informal sector. As a consequence of stagnation, unemployment and depreciation of capital stimulate participation in informal activities.

Some of the primary reasons to participate in the underground economy mentioned in the early literature are: (1) to evade taxes; (2) to avoid losing government benefits; (3) to circumvent regulations and licensing requirements; (4) a reaction by both firms and individual workers to labor unions; and (5) the impact of international competition. $^{7}$

In broader terms, the motives for participation can be economic and noneconomic. Economic reasons are related to unemployment and an inflexible formal labor market; a declining real price of capital; and the high cost of formal production. Non-economic motives are related to a greater flexibility and greater satisfaction in work; a complete use of their professional qualifications; and the increased leisure time. A very important element, motivating participation in the informal sector, seems to be the role of the state (Gershuny, 1979). These state-related variables and other motives are discussed by Renooy (1990) from the perspective of behavioral economics. He argues that there are two groups of factors which determine the decision to become active in the informal sector, more specifically, the 'structural' and 'opportunity' factors. The structural factors consist of financial pressure; sociopsychological pressure; and institutional constraints. The opportunity factors consist of individual background: skills, education, contacts and living situation, or nonindividual components: environment, cultural tradition, values and standards, and geographical factors. The author suggests that these 'opportunity' factors explain why different sorts of informal economies exist. The individual free choice affects the decision on tax payments based on a combination of inadequate information and a lack of any trust in the way taxes are spent. In an atmosphere in which the government loses the trust of the population and people no longer feel that government supports them, a step into the twilight economy will be taken much more easily. 
Many authors focus on tax evasion, as one aspect of the informal economy. Various studies argue that evasion of taxes is mainly caused by high tax rates and low audit probabilities (Clotfelter, 1983; Friedland et al., 1978; Baldry, 1987). Tanzi (1982) summarizes the main determinants of tax evasion as follows: (1) the perceived fairness of tax laws; (2) the attitude of taxpayers towards their government; (3) their basic religious and cultural characteristics; (4) the expected severity of penalties imposed on the tax evaders; and (5) the ease of evading taxes. In addition, Schneider and Neck (1993) present empirical evidence for the case of the Austrian tax reform of 1989, which says that a decreasing complexity of the tax system can promote the shadow economy by limiting various tax exemptions and reductions. Contrary to this evidence, Thießen (2003) finds that the Ukrainian shadow economy increases with higher tax complexity (i.e., the number of taxes, the ambiguous tax laws, the number and extent of tax exemptions). Although this contrast in findings could refer to the institutional differences between Austria (a developed country) and Ukraine (a less developed country), Thießen argues that "the implications of this study may go beyond the case of Ukraine because they suggest that the effective regulatory burden and tax system complexity appear to be quantitatively as important or even more important than the real monetary burden of taxes and social security contributions" (Thießen, 2003: 309). A more extensive coverage of tax evasion as a specific aspect of the informal sector will follow in section 5 .

Besides the evasion of taxes, another frequently mentioned reason for participation in the informal sector is the governmental over-regulation of the market sector, not only via taxes but also through, for example, legislation related to labor conditions, quality regulations, and production limits. This over-regulation increases the transaction costs of participation in the formal economy, so that it becomes relatively more appealing to switch to the informal sector. Johnson et al. (1997 and 1998b) find empirical evidence that more regulation indeed leads to a larger informal sector. Other motives related to the labor market are the increased number of unemployed people, the reduction in working hours, early retirements, and supportive social welfare systems (Schneider and Enste, 2000). Each of them provides incentives to individuals to search for new job opportunities, which are mostly available in the informal sector. However, in a recent study, Schneider and Mummert (2002) show that these motives do not always explain the individual participation in informal activities. Comparing the level of shadow economy in East and West Germany, they 
argue that social networks and institutional structures appear to be even more important.

\subsection{Studies in developing and transition countries}

\subsubsection{The relationship between the formal and informal sector}

The theories for developed countries, mentioned above, hold to a large extent for less developed countries as well. Therefore, I will mention some theoretical developments specific to the latter.

Early studies of the informal sector in developing countries consider the participants of informal activities as a 'reserve army' of labor, who mainly survive at low subsistence levels. For example, Swaminathan (1991) recognizes that the primary reason to start with research on the informal sector in developing countries was related to the problems of mass poverty and unemployment.

As mentioned above, the informal sector was present even in centrally planned economies. ${ }^{8}$ Theories describing informal activities in these economies are expected to have particular features. However, although the economic regime is substantially different than in Western economies, the informal sector acts as a safety valve for political discontent in planned economies as well. In addition, while in the West individuals earn incomes that are taxed, in socialist economies the resources are withheld at the outset by the overall imposition of scarcity as dictated by the central plan (Feige, 1989). Grossman (1982) has contributed significantly in providing evidence about the informal activities in these economies, especially for the USSR. His research has shown the following: (a) the demand for informal income and the supply of informal goods and services inevitably reinforced each other, and (b) exchange of favors in the form of access to goods or services was a salient feature of the Soviet informal sector. More specifically, some forms of informalization were: private lucrative use of socialist property; theft from the state and cooperatives; bribetaking by officials; and bribe-giving, in money or natura. He explains this phenomenon as a kind of cyclical reasoning, which starts with the state compensating for its loss through theft by paying lower wages. The individual in turn will consider this as an implicit justification to steal from the state -especially in a situation of pervasive goods shortages- and the circle closes. He concludes that these characteristics might have been similar in other communist countries of Eastern Europe. Further theoretical and empirical evidence about the informal sector in former 
socialist countries is given by Kornai (1993), Schneider (1997) and Lacko (1998). They observe that the informal sector activities in these countries, especially in the last period before transition, were much more widespread than in an 'average' market economy. This contradicts the common view that these countries experienced a relatively small informal sector, especially compared to developed countries.

Another typical feature of the informal sector in centrally planned economies is the existence of both the 'second' and the 'third' economies (Ellman, 1989). The 'second' economy consisted of hidden transactions of goods or services that were privately produced by individuals. The 'third' economy consisted of hidden activities by or within large enterprises, which were normally tolerated by the party officials in order to achieve the goals of the central plan.

Long after the early studies of centrally planned economies (e.g., by Grossman, 1982), the informal activities were again a subject of study, but this time during the transition period these countries were going through. In the literature, the following characteristics appear to be relatively specific to the informal sector in transition countries.

At the start of transition, the 'second' economy was legalized (i.e., production and exchange of private goods), although this does not exclude the possibility that some of the new private enterprises are operating in the informal sector (see below). The 'third' economy is unique to these countries and has remained the same: informal activities still take place within large enterprises (Dolgopiatova, 1998).

Considering the pro- or anti-cyclical relationship between the formal and informal sector, Fortuna and Prates (1989) observe that in developing countries the prospering period of export of manufactures entailed high levels of benefit for entrepreneurs, use of advanced technology, and growth in the scale of production. In addition, it fostered a process of informalization disguised as small independent entrepreneurship. Their observation indicates a pro-cyclical relationship. In transition countries, based on an interesting research about Hungary (covering the socialist as well as the transition period, 1980-1993), Arvay and Vertes (1995) conclude the following. There is a pro-cyclical relationship during the socialist period (before 1989) and an anti-cyclical relationship during the transition period (1989-1993). Johnson et al. (1999) argue in favor of the anti-cyclical relationship, because informal activities cannot make use of market-supporting institutions like courts of law and this may discourage investments and economic growth. This has occurred in Peru, as 
reported by De Soto (1989). Kaufmann and Kaliberda (1996) do not appear to be optimistic either. They claim that even if it is large, the informal sector is mostly a survival sector where the short-term turnover dominates the long term one, and where large scale and vital investments do not take place.

Some researchers argue that the informal sector in transition countries is characterized by almost zero entry and exit costs (Kaufmann and Kaliberda, 1996). This argument, however, has been criticized because research has shown that the informal sector does have such costs. ${ }^{9}$ The extensive use of barter is another typical element in some of these countries, especially Russia. Ellman (2000) summarizes several reasons for the growth of barter, such as criminalisation, tax evasion, a failed privatization strategy, a survival strategy for insolvent and loss-making firms, suppressed inflation or contagion, or some combination of these factors. In addition, the new small formal sector businesses in some of these countries hardly show any trend to expand and grow (Gaddy and Ickes, 1998). Some of the reasons put forward are: to avoid the attention of tax authorities and criminal organizations ${ }^{10}$ and often to delay paying wages to the workers. Finally, some argue that the rapid growth of the informal sector from a relatively low base has been a notable feature of some transition economies (Kaufmann and Kaliberda, 1996; and Commander and Tolstopiatenko, 1997). The expansion of the informal sector is also related to the large share of public expenditure in the GDP of these countries. This was especially the case in the early years of transition. In addition, less developed countries face a higher level of tax evasion due to their weakened fiscal authority, which in turn shifts a greater burden of revenue collection to monetary policy (Feige, 1990).

Finally, the recent institutional approach is particularly emphasized in the case of less developed countries, where the incompatibility between the formal and informal institutions is more evident than in the developed countries. ${ }^{11}$ Consequently, the occurrence of informal activities in the former countries is expected to be more dominant than in the latter. Gërxhani (2003) provides empirical evidence based on a household survey in Albania. 


\subsubsection{Motives and causes of informalization}

The majority of reasons for the existence and growth of informal activities converge for developed and less developed countries. There are a few specific differences, however.

Regarding developing countries, the low rate of industrialization and productivity, and the presence of surplus labor are listed as principal reasons why a dualistic system arose in the cities of the third world (Breman, 1980). In addition, it is accepted that due to the old economic mechanism (low technology and intensive use of cheap unskilled and semi-skilled labor) that these countries have, informal activities emerge and grow quite rapidly. This is basically one of the reasons why the informal sector in less developed countries is considered to be a sector for survival.

Johnson et al. (1998a) empirically find that the high tax and regulatory burden, the weak rule of law, and a high level of corruption can explain the high level of informal activities in some countries of Latin America.

Research about the informal sector under central planning recognizes some other basic motives of informalization (Grossman, 1982), such as: the presence of common socialist property, which is broadly regarded as 'up for grabs'; the constant consumer shortages; the universal price controls, physical allocation of goods, and other sorts of strict official regulations; the outright banning of a wide range of consumer articles and services; the bureaucratic inadequacies; the corrupted authorities; the political dissatisfaction; and the contrast between actual life and that predicted by the official ideology.

Regarding transition countries, the distinctive reasons of informalization are mainly related to the political, economic and social institutional causes of their transformation from centrally planned into free market economies. They involve: insufficient economic development (e.g., Kaufmann and Kaliberda, 1996, mention the low degree of economic liberalization and macroeconomic instability); a high tax burden and a complicated tax system (Thießen, 2003); a weak and complex legal and institutional framework (which is mainly due to the gap between the destruction of old institutions and the construction of new ones); inefficient enforcement mechanisms; a high level of corruption and bureaucratic incompetence among the government agents (Johnson 
et al., 1998a); the general lack of confidence in state institutions; the laissez passer approach towards the informal sector (i.e., the tolerance and insufficient control by the government); civil wars in some of these countries; and finally, the 'path dependency' (i.e., the conflict between the established economic and social norms in the past and the reaction to a new reality in the present).

\subsection{Theories on the informal sector: a critical assessment}

What can be concluded from this plethora of theories on the relationship between the informal and formal sector and on the motives for participation in the informal sector?

First of all, at first sight, almost every possible explanation has been given. To some extent, this is due to the fact that authors attempt to generalize conclusions that are based on a descriptive analysis of specific cases.

Secondly, relatively little attention is given to the behavior (based on preferences and restrictions) of individual agents, as a basis for theories on the informal sector. We will see in the following section, that this type of micro-economic analysis is more common in studies that focus more specifically on tax evasion.

Thirdly, the distinction between developed and less developed countries again appears to be useful. Section 4.2 mainly discussed theories specific to the latter. The most notable theoretical distinction was already observed when discussing definitions and criteria in section 3 . This is, that survival plays an important role in the decision to participate in the informal sector in less developed countries. As a consequence, this sector gives little opportunity to economic growth and accumulation. What is still missing, is a thorough economic theory supporting this theoretical distinction.

Finally, the analysis that appears to do best in combining various approaches, is Feige's theory on the relationship between the size of the informal sector on one hand and a clash between 'formal and informal institutions' on the other.

\section{Theories related to tax evasion}

Tax evasion is the aspect of the informal sector that has received most attention, especially by economists. According to Cowell (1990: 5), tax evasion is special because of the following reasons: (1) tax evasion is a fraud that is committed against a very special economic agent: the government; (2) it requires a delicate interplay of information among those involved in the black economy (evaders, investigators, the government); and (3) there is a special relationship between tax evasion and other 
topics central to the study of public economics. In addition, Andreoni et al. (1998) see important links between the economics of tax compliance and public finance, law enforcement, organizational design, labor supply and ethics. The relationship with public finance is reflected in the concepts of equity and efficiency. The enforcement of tax basically faces a classical principal-agent problem. "How can an authority with imperfect ability to monitor- design a taxation, audit, and punishment scheme to meet its revenue objectives?” (Andreoni et al., 1998: 819). The decision to evade taxes can also affect occupational choices, investment in human capital, and labor supply. Although for a while it was assumed that a rational individual will always evade, empirical evidence has shown that individuals comply with taxes at considerable rates. This has been explained by an individual sense of moral obligation (guilt or shame) to be honest.

Most of the theoretical contributions to the study of tax evasion can be summarized in two main categories, depending on how they see the role of government. The first assumes a benevolent dictator that maximizes social welfare. This includes the optimal taxation literature. The second sees government agents as rational utility maximizers. This is mainly represented by the Public Choice literature.

\subsection{Social welfare theories}

The best-known example of a taxation theory that assumes a benevolent dictator is optimal taxation theory. This has its origin in the seminal paper by Allingham and Sandmo (1972), followed by Srinivasan (1973), Singh (1973), Kolm (1973) and Yitzhaki (1974). The theory of optimal taxation came about in an attempt to determine the optimal tax policy (i.e., tax and penalty rates) such that the government will increase its revenue from a pool of taxpayers, who adjust their behavior to the taxies levied. One of its major assumptions is that the government is interested in and capable of maximizing the social welfare function. Taxpayers are often assumed to avoid taxes, not always to evade them. For example, a high income tax will decrease a rational worker's supply of labor, but no account is taken of the possibility that (s)he will supply labor in the informal sector in order to evade taxes. Another criticism of the optimal taxation theory is related to the neglect of the expenditure side of government activity (i.e., the use of revenue). Cowell and Gordon (1988) attempt to remedy this neglect. They were the first to consider both sides of the fiscal account by 
introducing public goods into the optimal taxation model. They find that under decreasing absolute risk aversion and under-provision of public goods, an improvement by the government financed through a higher tax rate, will lead to higher individual tax evasion. ${ }^{12}$ The authors themselves find this result a bit counterintuitive and relate it to the fact that the relationship between government and taxpayer has more dimensions than just the provision of public goods, something that their model does not capture. Besides being counterintuitive, this result does not correspond to most of the empirical and experimental literature (see Clotfelter, 1983; Crane and Nourzad, 1986; Friedland et al., 1978; Baldry, 1987). This literature finds a positive relationship not only between tax evasion and tax rate, but also between tax evasion and the perceived imbalance between tax payments and the public goods received in return. Bordignon (1992) took it from here and introduced a 'fairness' approach to income tax evasion. In his model, tax (non)compliance is dependent on tax structure, public expenditure and perceived evasion by other taxpayers. Assuming that the taxpayer can estimate the 'fair' terms of trade between his private consumption and government provision of public goods, Bordignon's model predicts that if the terms of trade offered by government through the tax system differ from own 'fair' terms of trade, the taxpayer will evade in order to re-establish fairness in his/her relationship with the other agents of the fiscal system. The results of this model show that some individuals comply with taxes even if it would be in their selfinterest not to do so; tax evasion increases with the tax rate; and the perceived 'fairness' of public expenditures, considering the tax payments, affects tax evasion. However, one should be careful in relying completely on the individual judgment of the 'fairness' of this trade-off. "The taxpayer's own standpoint in the system, rather than a sense of common concern, may be the driving force. 'Inequity' is in the eye of the beholder" (Cowell, 1990: 44).

Moreover, Cowell (1990) questions the basis on which tax evasion is considered to be negative. He argues that risks of detection and punishment cause welfare losses for evaders. A government should enforce the tax law only to the extent that it is sufficient to pay its bills. Naturally, Cowell raises the issue on whether this means tax evasion should be encouraged. In economic terms, it would be the case if the marginal gain in productive efficiency in the informal economy is greater (expected) than the marginal cost of being caught. However, he argues against this simplistic way of thinking. The decision to evade involves a public sector, whose spirit of cooperation is 
an important determinant. "The problem is that cheating might become epidemic, thus destroying the fiscal basis for the support of the state. Tight control is required to avoid the spread of mutiny below decks" (Cowell, 1990: 200). This is what Spicer (1986) called 'norms of compliance'. Entering this aspect into the picture, he asserts that a taxpayer will evade taxes only as long as the expected gains from taxes exceed the expected losses from fines and from the psychic costs related to evasion.

\subsection{Public Choice theories}

The field of Public Choice focuses on "the theory of the state, voting rules, voter behavior, party politics, the bureaucracy, and so on" (Mueller, 1989: 1). In this field, all agents involved are assumed to be rational utility maximizers. Its relationship to tax evasion is well put by Frey (1989: 118): "Government sets the instruments at its disposal so as to reach its own goals as well as possible, taking into account the reaction of the other agents, especially with respect to its re-election chance. Both sides of the fiscal account, that is, taxes and public expenditure, are used for this purpose." ${ }^{\prime 13}$ This is part of what he calls the theory of democratic economic policy. According to this theory, both formal and informal sector activities are the consequence of self-interested decision makers only interested in pursuing their own utility. Pommerehne et al. (1994) continued on the same idea, where the relationship between government public good provision, government waste, fairness aspects, and taxpayer compliance is explored in a theoretical model. Under a political regime of majority rule, they find that evasion is higher the greater the difference between the individual's optimal choice of public good provision and the actual level; and the higher the level of government waste in previous period.

All 'social welfare' models assume government officials to be honest and do the right thing not only in raising the revenue but also in using it fairly. Cowell (1990: 191) questions it: "Tax inspectors and auditors are real people like you and me. They are also, presumably, subject to the same sorts of temptations. What if the government's agents are themselves cheating the government?". This was theoretically studied in a model by Sanyal et al. (2000), where the behavior of tax revenue net of collection costs in a regime of widespread administrative corruption is explored. Under somewhat strict assumptions (e.g., a fixed fine rate or a government that does nothing to combat corruption), they find that in case of extensive evasion and collaboration between taxpayers and officials, government has the tendency to 
increase audit probability, sometimes higher than optimal. This increase in combination with a higher tax rate can result into a net revenue loss. In addition, they find that if there were a tendency of increased corruption as a result of higher taxes and fines, applying these latter tools would be ineffective for the government.

Wintrobe (2001) investigates the same issue, but from a different angle: the 'trust' aspect of social capital theory. "Even accepting the Public Choice point of view, one still has to assume that citizens trust their government to deliver the services it has promised in order to explain why they would "voluntarily' pay their taxes" (Wintrobe, 2001: 7). His starting point is the contradiction between the empirical evidence and the theory of rational utility maximizers' attitude towards taxes, that is, even if the government is completely to be trusted in allocating the promised services, a rational individual should completely free ride. Wintrobe goes against this prediction by assuming a positive relationship between a citizen's willingness to pay taxes and his/her level of trust in the government's honesty or in other individuals' civic spirit. Having assumed this, his model shows that "in the aggregate, the government tries to maximize the sum of citizens' surpluses -value of public goods and services minus taxes- from the public sector. Each citizen, in turn, is more likely to support the government, and, ceteris paribus, less likely to evade taxes, the greater the surplus he receives from the public sector" (Wintrobe, 2001: 9). Concerning the effect of an increase in tax rate on tax evasion, Wintrobe's model predicts a positive relationship if that means a lower surplus for the citizen. In the case of under-provided public goods, an increase in tax rates -used to improve the level of public goods- can yield less evasion of taxes because the tax increase contributes to a higher surplus for the citizens. Note that Wintrobe does not assume a benevolent dictator. In his model, governments need to be benevolent in order to gain the taxpayers' trust. His analyses do not end with the relationship between the citizens and the government only. Another hypothesis is as important: "The more citizens can trust their fellow citizens to pay taxes, the more willing they are themselves to do so and vice versa" (Wintrobe, 2001:10).

When discussing the issue of the 'optimal' level of tax evasion, Cullis and Jones (1998) argue that tax evasion can be seen as an opportunity for individuals to oppose the monopoly power that government imposes. Hence, "the more likely that government failure causes public funds to be allocated inefficiently, the lower will the 'loss' associated with tax evasion be" (Cullis and Jones, 1998: 208). Moreover, based 
on the work of the founders of Public Choice theory -Downs, 1957; Niskanen, 1971; Olson, 1971; Peltzman, 1976- they claim that this literature is much more suspicious of the objective of the various agents in the policy process. Politicians are votemaximizers; bureaucrats are budget-maiximizers; while interest groups are concerned with narrow interests and wealth maximization (Cullis and Jones, 1992).

\subsection{Theories on tax evasion: a critical assessment}

To obtain an understanding of individual tax evasion, the original optimal taxation theories do not provide useful insights (nor did they intend to). Apart from their simplistic assumptions, they lack empirical support: if applied to the decision to evade (as opposed to avoid) taxes, they would imply that almost everyone would evade because of the expected net benefits.

A first important step forward was the evaluation of the way in which benefits from government expenditures might enter the taxpayer's decision.

A more important step was given by the Public Choice input. By introducing rational government agents and their interaction with taxpayers in both the economic and political arena, this has opened completely new areas of research. In the following section, I will discuss various implications of this research.

\section{Implications of the Public Choice approach}

The early literature and the policy climate of the 1980s especially, were dominated by a 'pessimistic' view of the informal sector. According to this view, the informal sector was characterized by marginality and poverty. In addition, it was considered to be a source of unproductive labor and to have a residual character. However, in the 1990s, the attitudes of both governments and international agencies towards the informal sector were essentially reformist: they believed that the positive role played by the informal sector in the national economy could be enhanced by changes in policies at the macroeconomic level and at the enterprise level (Lubell, 1991). The subsequent research in the field has shown that the informal sector has potential for accumulation and development. These two viewpoints (pessimistic and optimistic) have been the center of a debate on the advantages and disadvantages of the informal sector. Nevertheles, as Schneider and Enste (2000: 107) state, "there is a common finding that the shadow economies of most transition and all investigated OECD countries have been growing over the past decade." 
The optimism - pessimism debate was mainly undertaken with a social welfare maximizing government in mind. What follows is an overview of the (policy) implications derived from the Public Choice perspective. These are categorized in four groups: the size of the informal sector; the political power of the agents involved; tax morale; and the consequences for less developed countries.

\subsection{The size of the informal sector}

When the market failed, "the state emerged as the lowest transaction costs institution for providing public goods and eliminating externalities" (Mueller, 1989: 335). However, contrary to the orthodox consensus, Public Choice theory does not simply assume that society will be better off by having more government, even in case of market failure. Frey (1989) focuses on individuals' (political demanders') position when determining the optimal balance between the formal and informal economy. ${ }^{14}$ He suggests that one way of achieving this optimum is by restricting the role of government and public bureaucracy (political suppliers). Schneider and Enste (2000) agree, but similar to Frey, they recognize that more regulations and laws is in (some) governments' interest since this means more material and political power for bureaucrats. "The signaling of 'fighting for law and order' might therefore be more useful for the chances of being reelected than radical reforms of the tax and the social security systems" (Schneider and Enste, 2000: 86). However, they also recognize that since for some politicians the shadow economy is an important source of votes, they may not be interested in fighting it.

Frey suggests another way to achieve an optimal combination of the formal and informal economies: by making government and public bureaucracy take better account of individuals' preferences, with respect to both, taxes and the level and structure of public expenditure. Frey proposes a more federalist decision-making power and a constitution of popular referenda and initiatives. However, he recognizes that the individuals and firms -involved in the informal economy- are not well organized and as a result possess less and significantly biased information about its benefits and costs.

This brings us to a topic that is at the core of the Public Choice analysis: the political power of agents in the decision-making bodies. 


\subsection{The political power of the agents involved}

Frey (1989) emphasizes the lack of voice -of agents involved in the informal sectorin the political-economic process. For example, interests of 'informal' workers are not represented by any trade union. Given this and the fact that most of these workers work part-time, they show no interest in becoming union members. Trade unions, on the other hand, are negatively affected in the membership rate if the informal economy increases. Hence, they emphasize the costs and disadvantages of this sector and oppose it. Likewise, the position of 'informal' producers is worse than the position of 'formal' producers. Competition from the informal economy, through flexibility in production, low costs of labor, no bureaucratic costs, and lower prices for goods and services, is strongly feared by 'formal' producers, who, having the possibility of influencing the political-economic process, also try to fight the informal economy. Frey completes the picture with the public administration, which according to him even more strongly opposes the informal economy. If the informal economy increases, workers and firms will reduce their tax payments and disobey regulations, which will be reflected in less material and political power for the agents in government. In addition, as suggested by Schneider and Enste (2000: 78), "a prospering shadow economy may cause severe difficulties for politicians because official indicators -on unemployment, labor force, income, consumption- are unreliable."

Cullis and Jones (1998) do not completely agree with the relevance of Frey's analysis. First, one should wonder about how much saying the individuals involved in the informal sector should have on the matter of its size. Second, referring to Collard (1989b), they mention that the ultimate goals of policy makers and bureaucracy do not necessarily converge. In addition to Cullis and Jones's comments, Frey's focus on the weak position of the individuals in this political process seems to disregard alternative ways for individuals to exert power and influence. "Government officials and bureaucrats may have some discretionary power to advance their own interests at the citizens' expense, but citizens' preferences, as registered through existing political institutions, may also constitute a consequential constraint” (Mueller, 1989: 344).

Moreover, Cullis and Jones (1998) point out that audits by tax authorities differs across (interest) groups. For example, farmers are generally known to constitute a powerful political interest group, which is often not 'disturbed'. Individuals who work in both the formal and informal sectors are often also 'left in peace', since they 
declare their income in one sector. Individuals who only work in the informal sector are the ones the inquiry of tax authorities is mostly focused on, since they are seen as 'stealers from the welfare state'.

\subsection{Tax morale and tax evasion}

Wintrobe (2001) mentions four aspects that are important in explaining tax evasion: (1) As long as individuals (and firms) do not believe the government is responsive to their wishes, even if it may be honest, they will attempt to evade their taxes; (2) As long as individuals (and firms) do not trust the government they will be unwilling to pay their taxes; (3) As long as individuals (and firms) believe the tax code is fair and is applied fairly, they will be more willing to pay their taxes; (4) As long as individuals (and firms) assume other individuals (and firms) are trying to evade taxes, they will attempt to evade themselves. Wintrobe proposes ways in which governments could respond to these aspects: the government needs more information on individuals' preferences; more measures should be taken to increase trust in the government; income earned, from whatever source, should be taxed in exactly the same way; government should increase the incentives for compliance among small evaders instead of going after big evaders. Finally, he emphasizes that one important way of solving the tax evasion problem is by developing the logic of democracy. "It must be emphasized that the rule of law must be enforced, and this includes appropriate penalties for tax evasion, but within the parameters of the rule of law, in a democracy the citizen should feel his relationship to the state to be one of exchange and not coercion" (Wintrobe, 2001: 13). An interesting extension of Wintrobe's analysis would be to study the response of government agents to the individuals he describes. For example, it might be in agents' interest to reciprocate the trust placed in them in order to keep the extent of tax evasion low.

Feld and Frey (2000) add a new element to this line of thought: constitutional differences (i.e., direct vs. representative democracy). Focusing on how tax authorities treat taxpayers in Switzerland, they find that constitutional differences between Swiss cantons affect the level of individual tax morale significantly. In other words, the more developed the institutions of direct citizen participation (i.e., referenda) are, the more important the relationship between tax authorities and taxpayers is (i.e., higher level of trust), and as a consequence the higher the tax morale. This is an important conclusion because they argue that tax evasion is not only dependent on the 
possibilities to evade taxes and enforcement mechanisms of tax authorities. One should not neglect the importance of taxpayers' tax morale, which "on the other hand, is not simply the result of one's upbringing. It depends on the interaction of taxpayers with tax authorities, on the legal framework, and on the constitutional environment" (Feld and Frey, 2000: 12).

\subsection{Less developed countries}

The Public Choice literature generally does not make a distinction between developed and less developed countries when describing the agents' interaction in relation to the informal sector. Although not often, it does recognize institutional country differences in this context. Cowell (1990) reports that evasion seems to differ noticeably across countries and across groups within one country. "These systematic differences among countries and among groups within one country cannot be dismissed as innate differences in taste or temperament. Inconvenient though it might appear for neat, individualistic models of economic behavior, people do seem to take into account the 'climate' within the group or groups to which they belong" (Cowell, 1990: 102). Based on an experimental study on tax evasion that compares a developed with a less developed country, Gërxhani and Schram (2002) find evidence of group and country differences. In Gërxhani (2002), it is shown that these differences can be attributed to an interaction between formal institutions (i.e., rules and laws) and informal institutions (i.e., norms and culture).

Cowell (1990) argues that in any country, distortion of information is at the core of individuals' decision to mislead the government. "Distortion of information lies at the heart of the state's problem of exercising control and authority in the economy" (Cowell, 1990: 40). However, the form this takes varies across countries. For example, in a centrally planned economy, this can take the form of 'report padding' (making false alterations to accounts concerning the fulfillment of the plan), whereas in developed and less developed (democratic) countries it is expressed in the form of tax evasion and related activities.

Thießen (2003) focuses on tax complexity and finds that its effect can be influenced by the specific institutions of a country. Based on a study in a less developed country, Ukraine, where arbitrary official behavior and ambiguous rules dominate, he suggests that tax simplification may have a positive impact on the wellbeing of a representative economic agent. The higher the tax complexity is, the larger 
is the space for the tax administration to undertake arbitrary measures. The lower the tax complexity, the less individual efforts and costs will be made to legally avoid taxes and easier it will be to assess the fairness of the tax system and other people's level of compliance. Hence, with respect to policy, he recommends that a decrease in the Ukraine's informal sector can be achieved through an extensive reduction in the regulatory burden.

Clark (1988) emphasizes that in countries going through transformation, or generally, in badly organized countries, the state officials' actions and decisions have a stronger effect on the informal economy than is generally assumed. He explains this by the ineffective infrastructure, poorly trained personnel and inefficient or absent enforcement mechanisms. In addition, he refers to government agents who exploit the possibilities offered by the informal economy, for example through bribery, blackmail, or personal access to the informal economy by which they compensate for their apparent or seemingly low wages. If the latter "is a significant feature of a country's bureaucracy, then combating corruption in the public sector may be a more effective way of controlling tax evasion in the private sector" (Cowell, 1990: 192).

Reversing the causality, by considering the effect of the informal sector on the political arena, Grossman (1982) asserts that in communist regimes appeared that the party in power attributed a negative political assessment to informal activities, because it weakened the authority of the dictatorship. This opinion seems to have remained even in the period of transition, with the only difference being that in this case 'it undermines the effective management of the economy by the state' (Kaufmann and Kaliberda, 1996).

\section{Summary and conclusions}

Starting from complete neglect, the phenomenon of informal economic activity has grown to be a subject of study by many researchers, both governmental and nongovernmental. This paper provides a general overview of the contributions to the literature on the informal sector, focusing on the criteria used to define the informal sector, the relationship between the formal and informal economy, tax evasion, and Public Choice analysis. Throughout the paper, these contributions are compared across two institutionally different types of countries: developed and less developed (developing and transition) countries. 
In the light of many aspects of the informal sector and consequently the variety of criteria describing each of them, several characterizations have emerged. Many researchers have considered this a disadvantage. Therefore, numerous unsuccessful efforts have been made to formulate a unique definition. In my view, there is no need for a universal definition, however. As long as researchers share a definition for each separate activity in the informal sector, there will be, first, a basis of comparison across studies (for each activity) and second, the sum of all activities will provide a picture of the informal sector as a whole.

A comparison of studies on the informal sector in developed countries and studies in less developed countries has shown that they converge on some basic criteria -undeclared labor, tax evasion, unregulated or unlincensed enterprises, illegality or criminality- used to characterize it. The essential divergence is related to the use of the 'survival' criterion. Consequently, studies in developed countries show that the informal sector offers possibilities for growth, whereas research in less developed countries provides evidence that survival is the main characteristic of the informal sector there. As Pardo (1995) observes, survival always 'legitimizes' law avoidance in extreme situations, where a conflict between morality and individual rationality emerges: agents justify their actions by lack of choice.

The informal sector will probably always exist. Although the consequences differ between developed and less developed countries, this phenomenon deserves full attention from all the societal agents involved. In spite of several (short run) positive outcomes, with the exception of some neoclassical economists and public choice theorists (De Soto, 1989; Buchanan et. al, 1990), there is a general agreement that, in the long run, the informal sector should be reduced in size or formalized. Although a reduction is very difficult (Schneider and Enste, 2003), it can only be possible when a low regulatory burden by a trustworthy state is combined with a democratic involvement of citizens in respecting the rule of law.

An important debate, only briefly referred to in this paper, is related to the significance of the informal sector and its relationship to the formal economy. Opinions are split between the negative and positive assessment. The first sees the informal sector as negligible, with a residual and marginal nature. The second considers the informal sector as a dynamic phenomenon, which might have a 
significant impact in the economy. However, considering the negative long-run implications of the existence of the informal sector, its (gradual) integration into the formal economy has been suggested. These opinions hold mostly for the informal sector in developing and transition countries and sometimes for developed countries.

The motives for individual participation in informal activities converge, to a large extent, for developed and less developed countries. The few specific differences are related to institutional country differences. The relationship between the formal and informal economy has been analyzed in the literature but the outcome is still ambiguous. The literature on developed countries argues more towards the positive effect, while in less developed countries, a negative relationship appears to be more dominant. A broader discussion can be found in Schneider and Enste (2000).

In spite of numerous studies on tax evasion, explicit country distinctions are seldomly made. This also holds for the contributions from the field of Public Choice. However, it should be acknowledged that the latter has allowed for a major step forward in understanding the dynamics of the informal sector. Public Choice theory has contributed to the literature by recognizing that the combination between the formal and informal economy is an outcome of various agents' (government, voters, interest groups) interaction. Although there are studies in this literature emphasizing the (purely economic) irrelevance of the concern about consequences of tax evasion, studies with a broader view on the matter -involving norms, cooperative behavior, and the well functioning of democracy- provide a much more balanced view on the relationship between the formal and informal economy. What this literature sometimes lacks is an application of Public Choice analysis to understand the specific characteristics of the informal sector in less developed countries (with the noticeable exception of the studies discussed in 6.4). In addition, with a few exceptions, Public Choice theory has not yet made a clear and useful distinction between the goals of policy makers and those of bureaucrats when dealing with the informal sector.

In sum, a considerable amount of work has been done to analyze the informal sector. However, we are still a long way from really understanding this phenomenon, which is of such major economic, political and social importance in all countries, developed as well as undeveloped. Two things are for sure: recognizing the distinction between the two types of countries puts us a step forward, and Public Choice has given our 
understanding an important boost. The next step should be a combination of these two developments. 


\section{References}

Adam, M. and Ginsburgh, V. (1985). The Effects of Irregular Markets on Macroeconomic Policy. Some Estimates for Belgium. European Economic Review 29(1): 15-33.

Alford, R.R. and Feige, E.L. (1989). Information Distortions in Social Systems: The Underground Economy and other Observer-Subject-Policymaker Feedbacks. In Feige (Ed.). The Underground Economy: Tax Evasion and Information Distortion, 57-81. Cambridge, Cambridge University Press.

Allingham, M.G. and Sandmo, A. (1972). Income Tax Evasion: A Theoretical Analysis, Journal of Public Economics 1: 323-38.

Alm, J. (1991). A Perspective on the Experimental Analysis of Taxpayer Reporting The Accounting Review, 66(3): 577-593.

Anderson, J.H. (1998). The Size, Origins, and Character of Mongolia's Informal Sector during the Transition. World Bank WP 1916.

Andreoni, J., Brian, E. and Feinstein, J. (1998). Tax Compliance. Journal of Economic Literature 36(2):818-60.

Arvay, J. and Vertes A. (1995). Impact of the Hidden Economy on Growth Rates in Hungary. Statistical Journal of the United Nations ECE 12: 27-39.

Baldry, J.C. (1987). Income Tax Evasion and the Tax Schedule: Some Experimental Results. Public Finance 42: 357-83.

Banerjee, N. (1982). Survival of the Poor. In Safa, H.I. (Ed.), Towards a Political Economy of Urbanization in Third World Countries, 175-88. Delhi, Oxford University Press, Bombay Calcutta Madras.

Beneria, L. (1989). Subcontracting and Employment Dynamics in Mexico City. In Portes, A., M. Castells, and L.A. Benton (Eds.), The Informal Economy: Studies in Advanced and Less Developed Countries, 173-89. Baltimore and London, The Johns Hopkins University Press.

Blau, P.M. and Scott W.R. (1963). Formal Organizations: A Comparative Approach. London, Routledge and Kegan Paul.

Boeke, J.H. (1953). Economics and Economic Policy of Dual Societies. New York.

Bordignon, M. (1992). A Fairness Approach to Income Tax Evasion. Journal of Public Economics 52(3): 345-62.

Breman, J.C. (1980). The Informal Sector in Research: Theory and Practice. Rotterdam: Erasmus University, Comparative Asian Studies Program 3. 
Bromley, R. and Gerry C. (1979). Casual Work and Poverty in Third World Cities. Chichester, Wiley and Sons.

Castells, M., and Portes A. (1989). World Underneath: The Origins, Dynamics, and Effects of the Informal Economy. In Portes, A., Castells, M., and Benton, L.A. (Eds.), The Informal Economy: Studies in Advanced and Less Developed Countries, 11-41. Baltimoreand London, The Johns Hopkins University Press.

Charmes, J. (1990). A Critical Review of Concepts, Definitions and Studies in the Informal Sector. In Turnham, D., Salome, B. and Schwarz, S. (Eds.), The Informal Sector Revisited, 10-49. Paris, OECD.

Clark G. (1988). Traders versus the state: anthropological approach to unofficial economies. Boulder, Weisveiw Press.

Clotfelter, C.T. (1983). Tax Evasion and Tax Rates: An Analysis of Individual Return. Review of Economics and Statistics 65(3):363-73.

Collard, D. (1989b). How much Investigation? In Collard, D. (Ed.), Fiscal Policy: Essays in Honor of Cederic Sandford, 104-15. Aldershot: Avebury.

Commander, S. and Tolstopiatenko A. (1997). A Model of the Informal Economy in Transition Economies. WP 122. The William Davidson Institute (University of Michigan).

Cowell, F. (1990). Cheating the Government. Cambridge: MIT Press.

Cowell, F.A. and Gordon, J.P.F. (1988). Unwillingness to Pay. Journal of Public Economics 36(3): 305-21.

Crane, S.E. and Nourzad, J. (1986). Inflation and Tax Evasion: An Empirical Analysis. Review of Economics and Statistics 68: 217-223.

Cullis, J. and Jones, P. (1998). Public Finance and Public Choice. Oxford University Press. $2^{\text {nd }}$ edition.

De Soto, H. (1989). The Other Path. The Invisible Revolution in the Third World. New York, Harper and Row.

Dolgopiatova, T.G. (1998). Neformal'nyi Sektor v Rossiiskoi ekonomike (Ed.), Moscow: Institute for Private Sector Development and Strategic Analysis.

Downs, A. (1957). An Economic Theory of Democracy. New York: Harper\& Row.

Ellman, M. (1989). Socialist Planning. Cambridge: Cambridge University Press, 2nd. edition.

Ellman, M. (2000). The Russian Economy under El'tsin. Europe-Asia Studies 52(8): 1417-32. 
Feige, E.L. (1979). How Big is the Irregular Economy? Challenge 22: 5-13.

Feige, E.L. (1981). The UK's Unobserved Economy: A Preliminary Assessment. Journal of Economic Affairs 1: 205-12.

Feige, E.L. (1989). The Underground Economies: Tax Evasion and Information Distortion (Ed.). Cambridge: Cambridge University Press.

Feige, E.L. (1990). Defining and Estimating Underground and Informal Economies: The New Institutional Economics Approach, World Development 18(7): 989-1002.

Feige, E.L. (1997). Underground Activity and Institutional Change: Productive, Protective and Predatory Behavior in Transition Economies. In Nelson, J.M., et al. (Eds.), Transforming Post-communist Political Economies, 21-35. National Academy Press, Washington, D.C..

Feld, L.P. and Frey, B.S. (2000). Trust Breeds Trust: How taxpayers are Treated. CESifo Working Paper 322, Munich, Germany.

Fields, G.S. (1990). Labor Market Modeling and the Urban Informal Sector: Theory and Evidence. In Turnham, D. et al. (Eds.), The Informal Sector Revisited, 49-69. Paris: OECD.

Fortuna, J.C. and Prates, S. (1989). Informal Sector versus Informalized Labor Relations in Uruguay. In Portes, A., Castells, M. and Benton, L.A. (Eds.), The Informal Economy: Studies in Advanced and Less Developed Countries, 78-95. Baltimore and London, The Johns Hopkins University Press.

Frey, B.S. (1989). How Large (or Small) should the Underground Economy be? In Feige, E.L. (Ed.), The Underground Economy: Tax Evasion and Information Distortion, 111-29. Cambridge: Cambridge University Press.

Friedland, N., Maital, S. and Rutenberg, A. (1978). A Simulation Study of Income Tax Evasion. Journal of Public Economics 10: 107-116.

Gaddy, C., and Ickes, B.W. (1998). To Restructure or Not to Restructure: Informal Activities and Enterprise Behavior in Transition. WP 13. The William Davidson Institute at the University of Michigan Business School.

Geertz (1963). Peddlers and Princes: Social Change and Economic Modernization in Two Indonesian Towns. University of Chicago.

Gershuny, J.I. (1979). The Informal Economy: Its Role in Post-Industrial Society. Futures 11: 3-15. 
Gershuny, J.I. (1983). Social Invitation and the Division of Labor. Oxford: Oxford University Press.

George, M.D. (1966). London Life in the Eighteenth Century. London, Peregrine.

Gërxhani, K. (2002). The Informal Sector in Transition: Tax Evasion in an Institutional Vacuum", Ph.D. thesis, University of Amsterdam, Tinbergen Institute Research Series, no. 265, Amsterdam: University of Amsterdam.

Gërxhani, K. and Schram, A. (2002). Tax Evasion and the Source of Income: An Experimental Study in Albania and the Netherlands. Discussion paper TI 2002098/1, Tinbergen Institute, University of Amsterdam.

Gërxhani, K. (2003). Tax Evasion in Transition: Outcome of an Institutional Clash? Testing Feige's Conjecture. Mimeo. University of Amsterdam.

Gouldner, A.W. (1954). Patterns of Industrial Bureaucracy. New York: Free Press. Greenfield, H.I. (1993). Invisible, Outlawed, and Untaxed, America's Underground Economy. Connecticut: Praeger, Westport.

Grossman, G. (1982). The 'Second Economy' of the USSR. In Tanzi (Ed.), The Underground Economy in the United States and Abroad. Lexington D.C. Heath. Harding, P. and Jenkins, R. (1989). The Myth of the Hidden Economy: Towards a New Understanding of Informal Economic Activity. Philadelphia: Open University Press, Milton Keynes.

Hart, K. (1971). Small Scale Entrepreneurs in Ghana and Development Planning. Journal of Development Planning, July.

Hart, K. (1973). Informal Income Opportunities and Urban Employment in Ghana. Journal of Modern African Studies 11(1): 61-89.

International Labor Office (1972). Employment, Income and Equality: A Strategy for Increasing Productivity in Kenya. Geneva: ILO.

Internal Revenue Service (1979). Estimates of Income Unreported on Individual Income Tax Returns. Washington DC: Government Printing Office.

Johnson, S., Kaufmann, D. and Shleifer, A. (1997). The Unofficial Economy in Transition. Washington D.C.: Brookings Papers on Economic Activity.

Johnson, S., Kaufmann, D. and Zoido-Lobaton, P. (1998a). Regulatory Discretion and the Unofficial Economy. American Economic Review 88(2):387-92. (1998b). Corruption, Public Finances and the Unofficial Economy. Discussion paper. Washington D.C.: The World Bank. 
Johnson, S., McMillan, J. and Woodruff, C. (1999). Why do Firms Hide? Bribes and Unofficial Activity after Communism. Discussion paper no. 2105. London: Center for Economic Policy Research.

Kaufmann, D. and Kaliberda, A. (1996). Integrating the Unofficial Economy into the Dynamics of Post-Socialist Economies: A Framework of Analysis and Evidence. Mimeo. World Bank.

Kolm, S.C. (1973). A Note on Optimum Tax Evasion. Journal of Public Economics 2: 265-70.

Kornai, J. (1993). The Evolution of Financial Discipline under the Postsocialist System. Kyklos 46(3): 315-36.

Lacko, M. (1998). The Hidden Economies of Visegrad Countries in International Comparison: A Household Electricity Approach. In Halpern, L. and Wyplosz, Ch. (Eds.), Hungary: Towards a Market Economy, 128-152. Cambridge (Mass.): Cambridge University Press.

Lubell, H. (1991). The Informal Sector in the 1980s and 1990s. OECD. Paris.

Mueller, D. (1989). Public Choice II. New York: Cambridge University Press.

Niskanen, W.A. (1971). Bureaucracy and Representative Government. New York: Aldine-Atherton.

North, D.C. (1997). Understanding Economic Change. In Nelson, J.M., et al. (Eds.), Transforming Post-communist Political Economies, 13-19. Washington, D.C., National Academy Press.

O’Higgins, M. (1989). Assessing the Underground Economy in the United Kingdom. In Feige, E.L. (Ed.), The Underground Economies: Tax Evasion and Information Distortion, 175-197. Cambridge: Cambridge University Press.

Olson, M. Jr, (1971). The Logic of Collective Action. Cambridge, Mass.: Harvard University Press.

Pardo, I. (1995). Morals of Legitimacy in Naples: Streetwise about Legality, SemiLegality, and Crime. European Journal of Sociology 36(1): 44-71.

Peltzman, S. (1976). Towards a More General Theory of Regulation. Journal of Law and Economics 19: 211-40.

Pommerehne, W., Hart, A. and Frey, B.S. (1994). Tax Morale, Tax Evasion, and the Choice of Tax Policy Instruments in Different Political Systems. Supplement to Public Finance/Finances Publiques 49:52-69. 
Portes, A., Castells, M. and Benton, L. A. (1989). Conclusion: The Policy Implications of Informality. In Portes, A., Castells, M. and Benton, L.A. (Eds.), The Informal Economy: Studies in Advanced and Less Developed Countries, 298-312. The Johns Hopkins University Press, Baltimore and London.

Renooy, P.H. (1990). The Informal Economy: Meaning, Measurement and Social Significance. Amsterdam: Netherlands Geographical Studies.

Sampson, S. (1987). The Second Economy of the Soviet Union and Eastern Europe. The ANNALS of the American Academy of Political and Social Science 493: 120-37.

Sanyal, A., Gang, I.N. and Goswami, O. (2000). Corruption, Tax Evasion and the Laffer Curve. Public Choice 105: 61-78.

Schneider, F. and Neck, R. (1993). The Development of the Shadow Economy under Changing Tax Systems and Structures. Finanzarchiv N.F. 50(3):344-69.

Schneider, F. (1997). The Shadow Economies of Western European Europe. Journal of the Institute of Economic Affairs 17(3): 42-48.

Schneider, F. (1998). Further Empirical Results of the Size of the Shadow Economy of 17 OECD Countries over Time. Discussion Paper. Linz, Austria: Department of Economics, University of Linz.

Schneider, F. and Enste, D.H. (2000). Shadow Economies: Size, Causes and Consequences. Journal of Economic Literature 38(1): 77-114.

Schneider, F. and Mummert, A. (2002). The German Shadow Economy: Parted in a United Germany? Finanzarchiv 86(3).

Schneider, F. and Enste, D.H. (2003). The Shadow Economy: An International Survey. Cambridge: Cambridge University Press.

Sethuraman, S.V. (1976). The Urban Informal Sector: Concept, Measurement and Policy. International Labor Review 114(1): 69-81.

Singh, B. (1973). Making Honesty the Best Policy. Journal of Public Economics 2: 257-263.

Smithies, E. (1984). The Black Economy in England since 1914. Dublin: Gill and Macmillan.

Srinivasan, T.N. (1973). Tax Evasion: A Model. Journal of Public Economics 2(4): 339-46.

Stedman Jones, G. (1984). Outcast London. Harmonds-worth, Peregrine. Revised edition. 
Swaminathan, M. (1991). Understanding the informal sector: A Survey. WIDER WP 95. Finland.

Tanzi, V. (1982). The Underground Economy in the United States and Abroad (Ed.). Lexington D.C. Heath.

Tanzi, V. (1986). The Underground Economy in the United States. Reply to Comments by Feige, Thomas, and Zilberfarb. IMF-Staff Papers 33(4): 799-811.

Thießen, U. (2003). The Impact of Fiscal Policy and Deregulation on Shadow Economies in Transition Countries: The Case of Ukraine. Public Choice 114: 295-318.

Thomas, J.J. (1992). Informal Economic Activity. LSE, Handbooks in Economics, London: Harvester Wheatsheaf.

Wintrobe, R. (2001). Tax Evasion and Trust. UWO Department of Economics Working Papers 200111. University of Western Ontario, Department of Economics.

Yitzhaki, S. (1974). Income Tax Evasion: A Theoretical Analysis. Journal of Public Economics 3(2): 201-2. 
Table 1: The average size of the shadow economy in developed and less developed countries

\begin{tabular}{|l|l|c|}
\hline \multicolumn{2}{|l|}{ Countries/continents } & Size as \% of GNP* \\
\hline Developed & OECD countries & 12 \\
\hline Transition & Former Soviet Union & 25 \\
& Middle and Eastern Europe & 20 \\
\cline { 1 - 2 } Developing & Africa & 44 \\
& Latin America & 39 \\
& Asia & 35 \\
\hline
\end{tabular}

Source: $\quad$ Based on Schneider and Enste (2003, p.37, table 4.5).

$(*)$ derived from Physical input method, 1989-1993 
Table 2: Criteria used to define the informal sector in studies of developed countries

\begin{tabular}{|c|c|c|c|c|c|c|c|c|c|c|c|c|}
\hline \multirow[t]{2}{*}{ Criteria } & \multicolumn{3}{|c|}{ Political (Legal Aspects) } & \multicolumn{6}{|c|}{ Economic } & \multicolumn{3}{|c|}{ Social } \\
\hline & $\begin{array}{l}\text { Governmt. } \\
\text { regulation }\end{array}$ & $\begin{array}{c}\text { illegal } \\
\text { activities }\end{array}$ & $\begin{array}{c}\text { national } \\
\text { statistics } \\
(G N P)\end{array}$ & $\begin{array}{c}\text { labor market } \\
\text { or status of labor } \\
\text { (unregul., no soc. } \\
\text { benef., } \\
\text { work condit., etc.) }\end{array}$ & $\begin{array}{l}\text { tax evas. } \\
\text { or } \\
\text { unreport. } \\
\text { income }\end{array}$ & $\begin{array}{l}\text { activity's } \\
\text { size } \\
\text { (small } \\
\text { scale of } \\
\text { operat.) }\end{array}$ & $\begin{array}{c}\text { professional } \\
\text { Status } \\
\text { (self-empl.or } \\
\text { family-based) }\end{array}$ & $\begin{array}{c}\text { activity's } \\
\text { regulation } \\
\text { or } \\
\text { registration }\end{array}$ & $\begin{array}{c}\text { national } \\
\text { statistics } \\
(G N P)\end{array}$ & networks & $\begin{array}{c}\text { autonomy } \\
\& \\
\text { flexibility }\end{array}$ & survival \\
\hline Breman (80) & + & & & + & & + & + & & & + & & \\
\hline Feige (79-89) & + & + & + & & + & & & + & + & & & \\
\hline Gershuny (83) & + & + & & & + & & & + & & & + & \\
\hline Tanzi (82-89) & & & + & & + & & & & + & & & \\
\hline $\begin{array}{l}\text { Castells, M. \& } \\
\text { Portes, A. (89) }\end{array}$ & + & + & & + & + & + & + & + & & + & + & - \\
\hline $\begin{array}{c}\text { Harding \& } \\
\text { Jenkins (89) }\end{array}$ & + & + & + & + & + & & & + & & + & + & \\
\hline Renooy $(90)^{\prime}$ & + & + & + & + & + & + & & + & + & + & + & \\
\hline $\begin{array}{c}\text { Intern. Rev. } \\
\text { Serv. (IRS)- } \\
(79)\end{array}$ & & & & & + & & & & + & & & \\
\hline $\begin{array}{c}\text { Inter. Lab. } \\
\text { Off.' (ILO) - } \\
\text { (72 on.) }\end{array}$ & + & & & + & & + & + & + & & + & & - \\
\hline $\begin{array}{c}\text { Swaminathan' } \\
\text { (91) }\end{array}$ & + & & & + & + & + & + & + & & & + & \\
\hline
\end{tabular}

(+) refers to the inclusion of the criterion in defining the informal sector;

(-) refers to the explicit exclusion of the criterion in defining the informal sector;

(') refers to those authors who have contributed to define the informal sector in both developed and less developed countries. 
Table 3: Criteria used to define the informal sector in studies of less developed countries

\begin{tabular}{|c|c|c|c|c|c|c|c|c|c|c|c|c|}
\hline \multirow[b]{2}{*}{$\begin{array}{l}\text { Criteria } \\
\text { Authors }\end{array}$} & \multicolumn{3}{|c|}{ Political (Legal Aspects) } & \multicolumn{6}{|c|}{ Economic } & \multicolumn{3}{|c|}{ Social } \\
\hline & $\begin{array}{l}\text { Governmt. } \\
\text { regulation }\end{array}$ & $\begin{array}{c}\text { illegal } \\
\text { activities }\end{array}$ & $\begin{array}{c}\text { national } \\
\text { statistics } \\
(G N P)\end{array}$ & $\begin{array}{c}\text { labor market } \\
\text { or status of labor } \\
\text { (unregul., no soc. } \\
\text { benef., } \\
\text { work condit., etc.) }\end{array}$ & $\begin{array}{l}\text { tax evas. } \\
\text { or } \\
\text { unreport. } \\
\text { income }\end{array}$ & $\begin{array}{l}\text { activity's } \\
\text { size } \\
\text { (small } \\
\text { scale of } \\
\text { operat.) }\end{array}$ & $\begin{array}{l}\text { professional } \\
\text { status } \\
\text { (self-empl. } \\
\text { or family- } \\
\text { based) }\end{array}$ & $\begin{array}{l}\text { activity's } \\
\text { regulation } \\
\text { or } \\
\text { registration }\end{array}$ & $\begin{array}{c}\text { national } \\
\text { statistics } \\
(G N P)\end{array}$ & networks & $\begin{array}{c}\text { autonomy } \\
\& \\
\text { flexibility }\end{array}$ & survival \\
\hline Hart $(71,73)$ & & & & + & & & + & + & & & & \\
\hline $\begin{array}{l}\text { Intern. Lab. } \\
\text { Of.' (ILO) - } \\
\text { (72 on.) }\end{array}$ & + & & & + & & + & + & + & & + & & \\
\hline Grossman (82) & + & + & & & & + & & + & & + & & + \\
\hline Banerjee (82) & & & & + & + & & & & & + & + & + \\
\hline Beneria (89) & + & & & + & + & + & & + & & + & + & \\
\hline Renooy $(90)^{\prime}$ & + & + & + & + & + & + & & + & + & + & + & + \\
\hline $\begin{array}{c}\text { Swaminathan' } \\
(91)\end{array}$ & + & & & + & + & + & + & + & & & + & + \\
\hline $\begin{array}{c}\text { Kaufmann \& } \\
\text { Kaliberda (96) }\end{array}$ & + & + & + & + & + & + & & + & & & & + \\
\hline $\begin{array}{c}\text { Commander \& } \\
\text { Tolstopiatenko } \\
(97) \\
\end{array}$ & + & + & & + & + & + & & + & & & & \\
\hline Anderson (98) & + & + & + & + & + & + & + & + & + & + & + & + \\
\hline
\end{tabular}

(+) refers to the inclusion of the criterion in defining the informal sector.

(-) refers to the explicit exclusion of the criterion in defining the informal sector;

(') refers to those authors who have contributed to define the informal sector in both developed and less developed countries. 
${ }^{1}$ Many terms have been used to name this phenomenon, since then. Nevertheless, there is no universal terminology, yet. We will adopt the generic term 'informal sector' in this literature survey, and extensively discuss its various meanings and dimensions.

${ }^{2}$ The distinction is between studies of the informal sector in developed countries and studies on less developed countries. Here, 'less developed countries' will refer to 'developing, centrally planned and transition countries'. According to a recent suggestion by Jim Thomas in personal correspondence, the 'informal sector' should be called the 'black economy' for developed countries, the 'informal sector' for developing countries, and the 'second economy' for transition countries. The main contribution of this paper is exactly the recognition of a distinction between these groups of countries, without focusing on the terminology used. Therefore, in line with most of the literature, the term 'informal sector' will continue to be used.

${ }^{3}$ In this paper, I will not discuss empirical studies. For a good recent review, see Schneider and Enste (2000).

${ }^{4}$ A casual labor market of a similar nature (informal) has also been identified in London in the $18^{\text {th }}$ and $19^{\text {th }}$ centuries (George, 1966; Stedman Jones, 1984).

${ }^{5}$ A great contribution to the same line of thought is the work of Thomas (1992), who uses three main criteria: (a) are market transactions involved?; (b) are the goods and services being produced legally?; and (c) are the methods of production and/or distribution legal?, as a way to distinguish different types of informal activities.

${ }^{6}$ Recall that this sub-criterion is used in the main criterion 'politics' as well.

${ }^{7}$ This refers to the move to underground activities due to the competition with cheaper Third World imports.

${ }^{8}$ According to Sampson (1987), the primary element of the 'informal sector' in these countries was private agriculture.

${ }^{9}$ One example is related to the existing network in an informal market, which increases the entry cost if a person is not part of the network. For more, see Fields (1990).

${ }^{10}$ It has been argued that sometimes they do not want to attract the attention of potential investors either, because these might see the business as a potential takeover target (for further comments, see Gaddy and Ickes, 1998).

${ }^{11}$ Formal and informal institutions should not be confused with the formal and informal sectors. As explained above, formal institutions refer to 'laws and regulations' and informal institutions refer to 'social norms'.

${ }^{12}$ For extensive comments, see Wintrobe (2001).

${ }^{13}$ For some authors (e.g., Wintrobe, 2001), the fact that both, taxes and expenditures are taken account of, is sufficient to consider an analysis as 'Public Choice'. This is a semantic question. In my view, a Public Choice analysis also takes the government decision-making process into account. This is why I categorize Cowell and Gordon (1988) in the 'social welfare' group, for example.

${ }^{14}$ Frey mentions that the existence of the informal sector is often considered to be beneficial because it is one of the most productive and enterprising sectors of the economy, without which the population would be materially much worse off. He also mentions its disadvantages related to its illegality, the erosion of tax morality and as a result a general breakdown of law and order, and the falling of public revenues. 